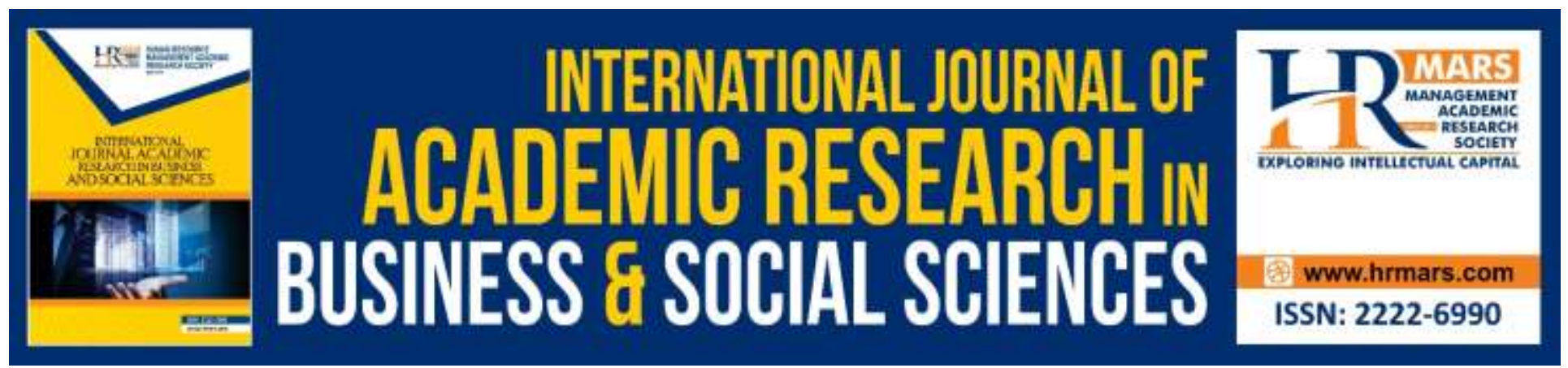

\title{
Participation in Physical Activity: The Motivation and Its Impact on Business Students' Academic Performance
} Hafizah Mohamad Hsbollah, Haslinda Hassan and Raja Haslinda Raja Mohd.
Ali

To Link this Article: http://dx.doi.org/10.6007/IJARBSS/v10-i13/6888

DOI:10.6007/IJARBSS/v10-i13/6888

Received: 11 December 2019, Revised: 01 January 2020, Accepted: 22 January 2020

Published Online: 13 February 2020

In-Text Citation: (Hsbollah et al., 2020)

To Cite this Article: Hsbollah, H. M., Hassan, H., \& Ali, R. H. R. M. (2020). Participation in Physical Activity: The Motivation and Its Impact on Business Students' Academic Performance. International Journal of Academic Research in Business and Social Sciences, 10(13), 51-61.

\section{Copyright: (C) 2020 The Author(s)}

Published by Human Resource Management Academic Research Society (www.hrmars.com)

This article is published under the Creative Commons Attribution (CC BY 4.0) license. Anyone may reproduce, distribute, translate and create derivative works of this article (for both commercial and non-commercial purposes), subject to full attribution to the original publication and authors. The full terms of this license may be seen

at: http://creativecommons.org/licences/by/4.0/legalcode

Special Issue: Upstream Research in Business and Management: Towards Socio-Economic Prosperity, 2020, Pg. 51 - 61

Full Terms \& Conditions of access and use can be found at http://hrmars.com/index.php/pages/detail/publication-ethics 


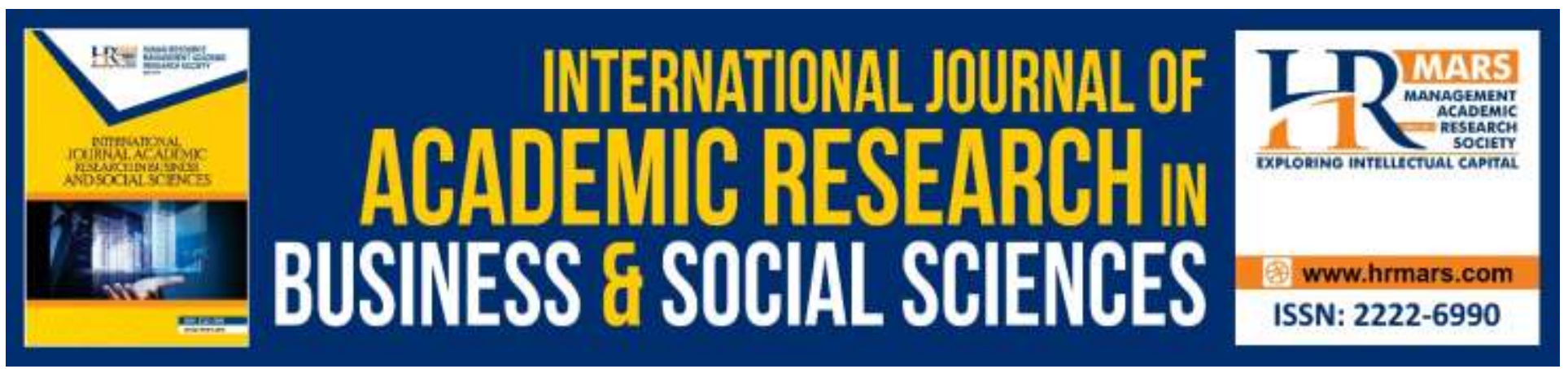

\title{
Participation in Physical Activity: The Motivation and Its Impact on Business Students' Academic Performance
}

\author{
Hafizah Mohamad Hsbollah, Haslinda Hassan and Raja Haslinda \\ Raja Mohd. Ali \\ Universiti Utara Malaysia, Malaysia \\ Email: hs.hafizah@uum.edu.my
}

\begin{abstract}
This study focuses on the motivational factors that affect business students' participation in physical activity and the impact of such participation on their academic performance. Data were collected by distributing questionnaires to business students in a Malaysian public university. Results indicate that of the eight motivational factors hypothesised as affecting students' participation in physical activity, only enjoyment, physical appearance, physical condition, and competition/ego are found to be significant. The impact of the business students' participation in physical activity on their academic performance is significant. Nonetheless, the relationship is negative, which indicates that being very active in physical activity could reduce the students' cumulative grade point average (CGPA). The findings of this study add to the body of knowledge and can be a useful reference on the motivational factors that influence business students' participation in physical activity and its negative relationship with academic performance. The findings could be used to help practitioners to create an intervention programme to promote physical activity and suggest solutions for students to achieve a university-life balance.
\end{abstract}

Keywords: Physical Activity, Sport, Exercise, Academic Performance, PALMS

\section{Introduction}

Physical activity is defined as all leisure and non-leisure body movements that result in energy expenditure (see, for example, Bherer, Erickson, \& Liu-Ambrose, 2013; Kilpatrick, Hebert, \& Bartholomew, 2005), such as sport and exercise. The awareness on the benefits of participating in physical activity has led to a growing number of research studies to understand what motivates people to participate in physical activity. This is because participating in physical activity is a choice of whether or not to be active, which needs to be made by individuals. Hence, understanding the 
reasons for participating in physical activity is crucial to motivate people to undertake more physical activity for a healthy lifestyle.

Prior studies have demonstrated that participation motives play a significant role in influencing physical activity behaviour. Such motives include enjoyment (e.g., Lewis, Williams, Frayeh, \& Marcus, 2016); physical fitness and condition (Yazici, Altun, Sözeri, \& Koçak, 2016; Zach, Bar-Eli, Morris, \& Moore, 2012); and physical appearance (Mishra \& Acharya, 2017; Santos, Ball, Crawford, \& Teixeira, 2016). Nevertheless, studies which have investigated the motives for participating in physical activity in Malaysia using the Physical Activity and Leisure Motivation Scale (PALMS) are limited. PALMS was designed as a comprehensive measurement for understanding people's reasons for engaging in physical activity, that is consistent with the Self Determination Theory.

Prior studies have reported varied results when the impact of participating in physical activity on students' academic performance was investigated. For instance, Kamal and Yusari (2014) found that students who are active in physical activity have higher academic performance than those who are inactive. Similarly, Elmagd et al. (2015); Ahmad (2018) revealed that there is a significantly positive correlation between physical activity and academic performance. While a positive relationship between physical activity participation and academic performance has been a focal point of many related studies, its negative relationship, however, has received considerably less attention. Tremblay, Inman, and Willms (2000), for instance, reported a negative relationship between academic achievement and the physical activity level. In their study on the relationship between physical activity and self-esteem and academic achievement among 12-year-old children, Tremblay et al. (2000); Abdullah, Daud, Ariff \& Shaifuddin (2018) revealed that one unit increase in the physical activity scale is associated with a reduction in test scores of $2-3 \%$ of a standard deviation. Their study provides an initial understanding that participation in physical activity might both positively or negatively impact academic performance.

This study conceptualises physical activity as activity in either sport (e.g., futsal and ping pong) or exercise (e.g., aerobics and jogging), or both. Studies which have measured both motivation in physical activity and the impact of such participation on academic performance, are still limited, especially in the context of public universities in Malaysia. Hence, what is still lacking in literature is a discourse on what the motivational factors that influence physical activity participation are and the impact of such participation on academic performance. Therefore, this study aims to achieve the following research objectives: firstly, to examine the motivational factors that influence the decision to participate in physical activity. Here, the PALMS is used to address this research question; and secondly, to investigate the impact of such participation on academic performance.

The remainder of this paper is structured as follows: Section two illustrates the research model and hypotheses of the study. Research methodology is explained in the third section, followed by results and discussion in the fourth section. The final section concludes the paper. 


\section{Research Model}

This study postulated nine hypotheses to address the research objectives. The first eight hypotheses address the first research question, which is using the PALMS as a means to examine the motivational factors for participating in physical activity. This is based on the argument made by Zach et al. (2012) who asserted that although the motive statements in PALMS have been generated in a recreational exercise context, it is however also suitable to be used in the sport context. Following PALMS, the motivational factors included in the research model are enjoyment, mastery, psychological condition, physical condition, affiliation, physical appearance, competition/ego and others' expectations (see Fig. 1 for the research model).

Enjoyment refers to the extent to which an individual participates in a physical activity because it is fun or doing something just because he/she wants to (Rogers, Morris, \& Moore, 2008). Mastery refers to the extent to which an individual participates in a physical activity to improve or acquire skills in the activity being undertaken (Rogers et al., 2008; Usaini \& Abubakar, 2015). Psychological condition is the extent to which an individual participates in a physical activity because it is part of overall mental health and to promote a healthy mind (Rogers et al., 2008). Hutzler, Oz, and Barak (2013) define competition/ego as the extent to which an individual participates in a physical activity because of the desire to master demands of a particular task, improve competency and performance or to be better than others. Rogers (2000) defines physical condition as the extent to which an individual participates in a physical activity to achieve the physical aspects of health and fitness and meet medical requirements. Affiliation is the extent to which an individual engages in physical activity due to the need to develop and maintain associations or relations with others (McDonald, Milne, \& Hong, 2002). Others' expectations refer to the extent to which an individual participates in a physical activity due to any reason related to pleasing others or doing it because it is expected by other people (Rogers, 2000). It is hypothesised that enjoyment $(\mathrm{H} 1)$, mastery $(\mathrm{H} 2)$, psychological condition (H3), physical condition ( $\mathrm{H} 4)$, affiliation ( $\mathrm{H} 5)$, physical appearance $(\mathrm{H} 6)$, competition/ego $(\mathrm{H} 7)$ and others' expectations $(\mathrm{H} 8)$ positively influence university students' participation in physical activity. 
INTERNATIONAL JOURNAL OF ACADEMIC RESEARCH IN BUSINESS AND SOCIAL SCIENCES

Vol. 10, No. 13, Special Issue: Upstream Research in Business and Management: Towards Socio-Economic Prosperity. 2020, E-ISSN: 2222-6990 @ 2020 HRMARS

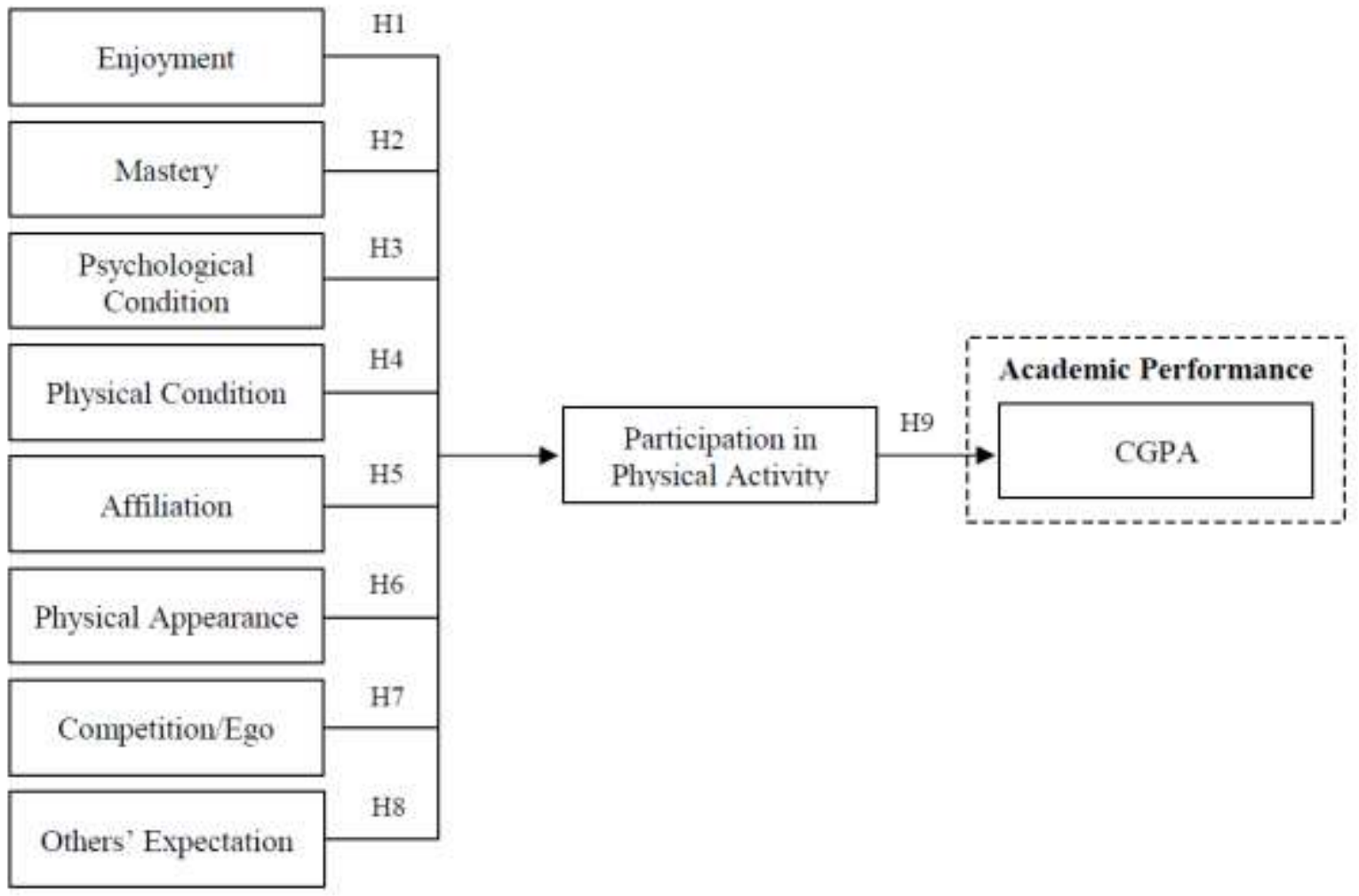

Fig.1: Research model

Academic performance refers to the extent to which a student has achieved his/her educational goals and is commonly measured by examinations or continuous assessment (Donnelly et al., 2016). In the context of physical activity participation among university students, Elmagd et al. (2015), Kamal and Yusari (2014), and Muñoz-Bullón, Sanchez-Bueno, and Vos-Saz (2017) found that students who are active in physical activity have better academic performance. It is then hypothesised that students' participation in physical activity is positively associated with academic performance (H9).

\section{Research Methodology}

Data Collection. A survey method was used to collect the data among the students in a Malaysian public university. The questionnaire was refined based on experts' review and pre-testing before the actual distribution. Four academicians and six sport centre officers participated at the pretesting stage. The population of this study is the students of Universiti Utara Malaysia (UUM). The unit of analysis is individual, which is the business students from the UUM College of Business. First year students, were however, excluded as their performance has yet to be measured. Hence, only second to final year students were selected as the key informants. Convenient sampling was used for sample selection. Five enumerators were appointed to administer the questionnaire to the respondents. Being aware of the sampling bias as the selection of the sample did not represent the target audience (Hair, Black, Babin, Anderson, \& Tatham, 2010), the findings from the survey should not be generalised. 
INTERNATIONAL JOURNAL OF ACADEMIC RESEARCH IN BUSINESS AND SOCIAL SCIENCES

Vol. 10, No. 13, Special Issue: Upstream Research in Business and Management: Towards Socio-Economic Prosperity. 2020, E-ISSN: 2222-6990 @ 2020 HRMARS

All the 450 questionnaires distributed were received. Twenty-two responses with major missing values were excluded from further analysis. A total of 428 usable questionnaires was therefore analysed (i.e., a $95 \%$ response rate). Of the responses received, $63 \%$ and $37 \%$ are female and male, respectively. Most of the respondents (98\%) are in the range of 19-24 years old, and majority of them are in semester three. In terms of academic programme, most of the respondents are from Accounting (17.76\%), followed by Economics (14.95\%), Business Administration (10.75\%), Islamic Finance and Banking (10.05\%), and Muamalat Administration (10.5\%).

Measures. All items used in the study were adapted from existing literature on PALMS (Chowdhury, 2012; Molanorouzi, Khoo, \& Morris, 2014; Zach et al., 2012). A 5-point Likert scale from "strongly disagree" to "strongly agree" was used to measure the motives for participating in physical activity. Academic performance, measured by CGPA, ranged from 1.50-2.00, 2.01-2.50, 2.51-3.00, 3.01-3.50 to 3.51-4.00. Participation in physical activity was measured by the frequency of involvement in sport or exercise, or both activities in a week. The involvement was rated based on "never", "1-3 times", "4-6 times", "7-9 times" and "more than 10 times" in a week.

\section{Results and Discussion}

Partial Least Squares (PLS) (via SmartPLS version 2.0 software) was used for statistical analysis. PLS is a structural equation modelling (SEM) technique that allows testing and estimating causal relationships among multiple independent and dependent constructs simultaneously. A two-step approach was used in the analysis: assessment of the measurement model and assessment of the structural model.

Assessment of the Measurement Model. In this analysis, construct reliability, convergent validity, and discriminant validity were tested. Table 1 shows the item loadings, composite reliability (CR), and average variance extracted (AVE). The composite reliability of each measure ranges from .834 to .960 , indicating that the construct is reliable as it exceeds the recommended threshold value of .70 (Fornell \& Larcker, 1981; Hair et al., 2010). All loadings exceed the minimal threshold value of .70 (Fornell \& Larcker, 1981), suggesting good indication of item reliability. Consequently, none of the items were removed. The value for the AVE for each measure is also greater than the threshold value of .50, as suggested by Hair et al. (2010). Hence, all items have adequate reliability and convergent validity.

TABLE 1 : Item loadings, AVE, and CR

\begin{tabular}{|c|c|c|c|c|c|c|c|c|c|}
\hline Construct & Item & Loadings & AVE & CR & Construct & Item & Loadings & AVE & $\mathrm{CR}$ \\
\hline \multirow{5}{*}{$\begin{array}{l}\text { Affiliation } \\
\text { (AFF) }\end{array}$} & AFF1 & .887 & .783 & .947 & \multirow{8}{*}{$\begin{array}{l}\text { Mastery } \\
\text { (MAST) }\end{array}$} & MAST1 & .892 & .780 & .955 \\
\hline & AFF2 & .914 & & & & MAST2 & .912 & & \\
\hline & AFF3 & .918 & & & & MAST3 & .866 & & \\
\hline & AFF4 & .865 & & & & MAST4 & .903 & & \\
\hline & AFF5 & .836 & & & & MAST5 & .840 & & \\
\hline \multirow{3}{*}{$\begin{array}{l}\text { Physical } \\
\text { appearance } \\
\text { (APP) }\end{array}$} & APP1 & .839 & .724 & .929 & & MAST6 & .883 & & \\
\hline & APP2 & .891 & & & & OTH1 & .812 & .709 & .936 \\
\hline & APP3 & .886 & & & & OTH2 & .872 & & \\
\hline
\end{tabular}


INTERNATIONAL JOURNAL OF ACADEMIC RESEARCH IN BUSINESS AND SOCIAL SCIENCES

Vol. 10, No. 13, Special Issue: Upstream Research in Business and Management: Towards Socio-Economic Prosperity. 2020, E-ISSN: 2222-6990 @ 2020 HRMARS

\begin{tabular}{|c|c|c|c|c|c|c|c|c|c|}
\hline Construct & Item & Loadings & AVE & CR & Construct & Item & Loadings & AVE & CR \\
\hline & APP4 & .791 & & & \multirow{4}{*}{$\begin{array}{l}\text { Others' } \\
\text { expectations } \\
\text { (OTH) }\end{array}$} & OTH3 & .790 & & \\
\hline & APP5 & .843 & & & & OTH4 & .848 & & \\
\hline \multirow{5}{*}{$\begin{array}{l}\text { Competit } \\
\text { Ego } \\
\text { (COMP) }\end{array}$} & COMP1 & .918 & .827 & .960 & & OTH5 & .872 & & \\
\hline & COMP2 & .932 & & & & OTH6 & .855 & & \\
\hline & COMP3 & .902 & & & \multirow{3}{*}{$\begin{array}{l}\text { Physical } \\
\text { condition } \\
\text { (PHY) }\end{array}$} & PHY1 & .892 & \multirow[t]{3}{*}{.822} & \multirow[t]{3}{*}{.958} \\
\hline & COMP4 & .917 & & & & PHY2 & .915 & & \\
\hline & COMP5 & .878 & & & & PHY3 & .912 & & \\
\hline $\begin{array}{l}\text { Academic } \\
\text { performance }\end{array}$ & CGPA & \multicolumn{3}{|c|}{ Single-item construct } & & PHY4 & .909 & & \\
\hline Enjoyment & ENJ1 & .900 & .824 & .949 & & PHY5 & .905 & & \\
\hline (ENJ) & ENJ2 & .923 & & & \multirow{5}{*}{$\begin{array}{l}\text { Psychological } \\
\text { condition } \\
\text { (PSY) }\end{array}$} & PSY1 & .880 & \multirow[t]{5}{*}{.807} & \multirow[t]{3}{*}{.954} \\
\hline & ENJ3 & .910 & & & & PSY2 & .910 & & \\
\hline & ENJ4 & .897 & & & & PSY3 & .912 & & \\
\hline \multirow{2}{*}{$\begin{array}{l}\text { Participation } \\
\text { in PA }\end{array}$} & FreEXE & .788 & .715 & .834 & & PSY4 & .914 & & \\
\hline & FreSport & .900 & & & & PSY5 & .874 & & \\
\hline
\end{tabular}

The Fornell-Larcker criterion was used to evaluate discriminant validity where the square root of AVE was examined, and all the inter-construct correlations were compared. As shown in Table 2, the square roots of the AVE of each construct are greater than the cross-correlations between them, thereby suggesting discriminant validity.

TABLE 2 : Discriminant validity

\begin{tabular}{lcccccccccc}
\hline & CGPA & AFF & COMP & ENJ & MAST & OTH & $\begin{array}{c}\text { Participation } \\
\text { In PA }\end{array}$ & APP & PHY & PSY \\
\hline Academic & $\begin{array}{c}\text { Single- } \\
\text { item }\end{array}$ & & & & & & & & & \\
Performance & $\begin{array}{c}\text { construct } \\
\text { cons }\end{array}$ & & & & & & & & & \\
AFF & -.100 & .885 & & & & & & & & \\
COMP & -.057 & .428 & .910 & & & & & & & \\
ENJ & -.164 & .547 & .460 & .908 & & & & & & \\
MAST & -.109 & .569 & .573 & .723 & .883 & & & & & \\
OTH & -.143 & .229 & .539 & .191 & .276 & .842 & & & & \\
Participation & -.107 & .269 & .338 & .357 & .344 & .236 & .846 & & & \\
in PA & & & & & & & & & & \\
APP & -.098 & .436 & .533 & .467 & .519 & .335 & .298 & .851 & & \\
PHY & -.059 & .606 & .477 & .626 & .655 & .165 & .221 & .580 & .907 & \\
PSY & -.059 & .523 & .399 & .645 & .626 & .100 & .238 & .492 & .720 & .898 \\
\hline
\end{tabular}

Assessment of the Structural Model. Testing the structural model covers path coefficients (i.e., the strength and the sign of the theoretical relationships), hypotheses testing, and variance explained by 
INTERNATIONAL JOURNAL OF ACADEMIC RESEARCH IN BUSINESS AND SOCIAL SCIENCES

Vol. 10, No. 13, Special Issue: Upstream Research in Business and Management: Towards Socio-Economic Prosperity. 2020, E-ISSN: 2222-6990 @ 2020 HRMARS

the independent variables. A bootstrap procedure with 1,000 resamples was used for hypotheses testing (Deng, Allison, Fang, Ash, \& Ware, 2013). The results of the structural model are summarised in Table 3. Of the eight variables tested on the motivation for participating in physical activity, four are supported: enjoyment $(\mathrm{H} 1)$, physical conditions (H4), physical appearance (H6), and competition/ego (H7). The impact of participation in physical activity on academic performance is found to be significant. The variance explained for participation in physical activity and academic performance is $19 \%$ and $1.2 \%$, respectively.

TABLE 3 : Hypotheses Testing

\begin{tabular}{|c|c|c|c|c|c|c|}
\hline & Hypotheses & $ß$ & $\begin{array}{c}\text { Standard } \\
\text { error }\end{array}$ & $\begin{array}{c}\text { t- } \\
\text { value }\end{array}$ & $\begin{array}{c}p- \\
\text { value }\end{array}$ & Result \\
\hline $\mathrm{H} 1$ & ENJ $\rightarrow$ Participation in PA & .227 & .062 & 3.648 & .000 & Supported $^{* *}$ \\
\hline $\mathrm{H} 2$ & MAST $\rightarrow$ Participation in PA & .097 & .071 & 1.378 & .169 & Not supported \\
\hline H3 & PSY $\rightarrow$ Participation in PA & -.003 & .063 & .042 & .966 & Not supported \\
\hline $\mathrm{H} 4$ & $\mathrm{PHY} \rightarrow$ Participation in PA & -.165 & .071 & 2.330 & .020 & Supported ${ }^{* *}$ \\
\hline H5 & AFF $\rightarrow$ Participation in PA & .070 & .053 & 1.321 & .187 & Not supported \\
\hline H6 & APP $\rightarrow$ Participation in PA & .116 & .055 & 2.096 & .036 & Supported ${ }^{* *}$ \\
\hline $\mathrm{H} 7$ & COMP $\rightarrow$ Participation in PA & .128 & .069 & 1.853 & .064 & Supported ${ }^{*}$ \\
\hline $\mathrm{H} 8$ & OTH $\rightarrow$ Participation in PA & .070 & .055 & 1.275 & .203 & Not supported \\
\hline H9 & $\begin{array}{l}\text { Participation in PA } \rightarrow \text { Academic } \\
\text { performance }\end{array}$ & -.107 & .052 & 2.081 & .038 & Supported ${ }^{* *}$ \\
\hline
\end{tabular}

*Found significant at .10; ** Found significant at .05

The significant motivational factors suggest that business students tend to participate in physical activity for fun (i.e., enjoyment), to maintain and improve their physical strength and health (i.e., physical condition), to improve their appearance in terms of losing weight and body shape (i.e., physical appearance), and to master particular tasks, improve competency and performance or to be better than the others (i.e., competition/ego). On the other hand, mastery is found to have no relationship with participation in physical activity, which contradicts previous findings (see for example, Molanorouzi et al., 2015). One plausible explanation is that business students participate in physical activity for fun; hence, their aim is not on improving or acquiring specific skills related to the physical activity.

This study reveals psychological condition is not significant in explaining the motivation for participating in physical activity among the business students. As young adults (i.e., 19-24 years old), they can find other alternatives to release tension or pressures faced, such as playing online games and connecting with friends via social media. This reason could also explain why the affiliation factor does not motivate business students to participate in physical activity. They prefer to develop and maintain new relationships with virtual friends via the social media platform. Consistent with Molanorouzi et al. (2015), our study provides evidence that the others' expectations factor is not relevant in explaining why business students participate in physical activity. Specifically, Molanorouzi et al. (2015) found others' expectations as an important motive for participating in physical activity for middle-aged adults but not for young adults. 
In terms of the impact of physical activity participation on academic performance, we found that participation in physical activity is significant and negatively associated with academic performance. This finding suggests that if the independent variable increases by a unit, the dependent variable will decrease by .107. This negative relationship is consistent with a study by Tremblay et al. (2000). A plausible explanation for this finding is that frequent participation in physical activity may reduce the time available for studying. In other words, frequent involvement in physical activity could interfere with the learning process (e.g., attendance in class) and be a distraction for the students in class due to their fatigue and lack of sleep. This is consistent with So (2012) who argued that physical activity is time consuming and would potentially deprive students' study time. The more frequently the students participate in physical activity, the lesser the time they have to keep up with academic commitment, which might lead to poor academic performance. Hence, a balance must be struck between studying and participating in physical activity, which is crucial for the students to maintain a healthy life style and achieve academic success.

\section{Conclusion}

This study reveals two important findings. Firstly, enjoyment, physical condition, physical appearance, and competition/ego are the important motivational factors that influence business students' participation in physical activity. Secondly, frequent participation in physical activity has a negative impact on academic performance.

The implication of the study is that the ministry of higher education and public universities could take greater efforts to promote physical activity participation by focusing on these four determinants of enjoyment, physical condition, physical appearance and competition/ego. In addition, balancing both physical activity and academic achievement could be a real challenge for the students. While other students who take the same course load could be fully involved in learning activities and preparing for the examination, students who are active in physical activity must have the determination to prioritise and plan their time accordingly. Hence, some intervention programmes could be introduced to help the students to strike the right balance between physical activity and their studies.

\section{Acknowledgement}

The authors gratefully acknowledge Universiti Utara Malaysia for financially supporting this research (S/O code: 13514).

\section{References}

Abdullah, C. Z. H., Daud, S. C., Ariff, N. Z. Z. M., \& Shaifuddin, N. (2018). Bibliographic Control and Resource Description Access Standard in Malaysia. International Journal of Academic Research in Progressive Education and Development, 7(3), 96-102.

Ahmad, B. A. A. (2018). The Internal Auditing Procedures Effectiveness in Using Accounting Information System to Assess Fraud in Jordanian Commercial Banks, International Journal of Academic Research in Accounting, Finance and Management Sciences 8 (3): 291-298.

Bherer, L., Erickson, K., \& Liu-Ambrose, T. (2013). A review of the effects of physical activity and exercise on cognitive and brain functions in older adults. Journal of Aging Research, 1-8. 
INTERNATIONAL JOURNAL OF ACADEMIC RESEARCH IN BUSINESS AND SOCIAL SCIENCES

Vol. 10, No. 13, Special Issue: Upstream Research in Business and Management: Towards Socio-Economic Prosperity. 2020, E-ISSN: 2222-6990 @ 2020 HRMARS

Chowdhury, D. R. (2012): Examining reasons for participation in sport and exercise using the physical activity and leisure motivation scale (PALMS). (Unpublished doctoral dissertation). Victoria University, Australia.

Deng, N., Allison, J. J., Fang, H. J., Ash, A. S., \& Ware, J. E. (2013). Using the bootstrap to establish statistical significance for relative validity comparisons among patient-reported outcome measures. Health and Quality of Life Outcomes, 11, 89.

Donnelly, J. E., Hillman, C. H., Castelli, D., Etnier, J. L., Lee, S., Tomporowski, P., Lambourne, K., \& Szabo-Reed, A. N. (2016). Physical activity, fitness, cognitive function, and academic achievement in children: A systematic review. Medicine and Science in Sports and Exercise, 48(6), 1197-1222.

Elmagd, M. A., Mossa, A. H., Sami, M. M., El-Marsafawy, T. S., Al Jadaan, O., \& Eldin, M. S. (2015). The impact of physical activity on the academic performance among medical and health sciences students: A Cross sectional study from RAKMHSU-Ras Alkhaimah-UAE. International Journal of Physical Education, Sports and Health, 2(1), 92-95.

Fornell, C., \& Larcker, D. F. (1981). Evaluating structural equation models with unobservable variables and measurement error. Journal of Marketing Research, 18(1), 39.

Hair, J., Black, W., Babin, B., Anderson, R., \& Tatham, R. (2010). Multivariate data analysis. Upper Saddle River, N.J: Pearson Prentice Hall

Hutzler, Y., Oz, M., \& Barak, S. (2013). Goal perspectives and sport participation motivation of special Olympians and typically developing athletes. Research in Developmental Disabilities, 34(7), 2149-2160.

Kamal, A. A., \& Yusari, N. (2014). Malaysian students' involvement in physical activity and the impact on academic achievement. Standard Journal of Education and Essay, 2(2), 032-038.

Kilpatrick, M., Hebert, E., \& Bartholomew, J. (2005). College students' motivation for physical activity: Differentiating men's and women's motives for sport participation and exercise. Journal of American College Health, 54(2), 87-94.

Lewis, B. A., Williams, D. M., Frayeh, A. L., \& Marcus, B. H. (2016). Self-Efficacy versus Perceived Enjoyment as Predictors of Physical Activity Behaviour. Psychology \& Health, 31(4), 456-469.

McDonald, M.A., Milne, G.R., \& Hong, J. (2002). Motivational factors for evaluating sport spectator and participant markets. Sport Marketing Quarterly, 11(2).

Mishra, M., \& Acharya, A. (2017). Comparison of exercise versus sport participation motives among university students of Odisha state. International Journal of Physical Education, Sports and Health, 4(3), 01-04.

Molanorouzi, K., Khoo, S., \& Morris, T. (2014). Validating the physical activity and leisure motivation scale (PALMS). BMC Public Health, 14, 1-12.

Muñoz-Bullón, F., Sanchez-Bueno, M. J., \& Vos-Saz, A. (2017). The influence of sports participation on academic performance among students in higher education. Sport Management Review, 20(4), 365-378.

Rogers, H. (2000). Development of a recreational exercise motivation questionnaire. (Unpublished doctoral dissertation). Victoria University of Technology, Australia.

Rogers, H., Morris, T., \& Moore, M. (2008). A qualitative study of the achievement goals of recreational exercise participants. The Qualitative Report, 13(4), 706-734. 
Santos, I., Ball, K., Crawford, D., \& Teixeira, P. J. (2016). Motivation and barriers for leisure-time physical activity in socioeconomically disadvantaged women. PLOS ONE, 11(1), e0147735.

So, W.-Y. (2012). Association between physical activity and academic performance in Korean adolescent students. BMC Public Health, 12(1), 258.

Tremblay, M.S., Inman, J.W., \& Willms, J.D. (2000). The relationship between physical activity, selfesteem, and academic achievement in 12-year-old children. Pediatric Exercise Science, 12(3), 312-323.

Hsbollah, H. M., Hassan, H., \& Ali, R. H. R. M. (2020). Participation in Physical Activity: The Motivation and Its Impact on Business Students' Academic Performance. International Journal of Academic Research in Business and Social Sciences, 10(13), 1-11.

Yazici, T., Altun, M., Sözeri, B., \& Koçak, S. (2016). Understanding college student's motivation for physical activity participation: The role of gender, sport type and activity level. Journal of Human Sciences, 13(3), 5189-5200.

Zach, S., Bar-Eli, M., Morris, T., \& Moore, M. (2012). Measuring motivation for physical activity: An exploratory study of PALMS-The physical activity and leisure motivation scale. Athletic Insight, 4(2), 141-154. 